\title{
Será que nada vai acontecer? Tempo e melancolia na poética da Legião Urbana
}

Henrique Pinheiro Costa Gaio*

Resumo: O rock nacional, ao longo da década de 1980, tornou-se uma importante forma de expressão cultural de massa. Não somente pelo processo de profissionalização da indústria cultural, que ampliou significativamente o consumo e a circulação, mas, sobretudo, por reverberar certos anseios e angústias específicas daquela geração. Tendo em vista tal movimento de autonomização e de construção de uma linguagem peculiar, o objetivo deste ensaio é indicar certa sensibilidade sobre o tempo que ganha contorno na poética da banda Legião Urbana (1982-1996) entre 1985 e 1991. Trata-se, portanto, de uma tentativa de articulação entre experiência do tempo e uma estética melancólica, atendo-se aos afetos mobilizados e ao jogo entre esperança e frustração.

Palavras-chave: Legião Urbana. Temporalidade. Melancolia.

\section{Feliz ano novo: fragmentos do tempo e perspectivas de futuro}

No dia $1^{\underline{a}}$ de janeiro de 1985, a primeira página da Folha de S. Paulo destacava: "Todos eles são Deus e ainda têm esperanças". O jornal havia encontrado na lista telefônica 79 assinantes com sobrenome "Deus". A matéria de capa trazia trechos de entrevistas com seus assinantes sobre as expectativas para o ano, elencando diferentes desejos, desde a realização do sonho individual da compra

"Doutor em História pela Pontifícia Universidade Católica do Rio de Janeiro PUC-Rio. Pesquisador na Comunidade de Estudos de Teoria da História da Universidade Estadual do Rio de Janeiro - UERJ. E-mail: henriquecgaio@gmail.com 
da casa própria até o ecumênico alcance da paz mundial. Além do protocolar otimismo diante da virada do ano e da suposta possibilidade de um recomeço, o jornal parecia agenciar sentimentos e projeções de seus assinantes. $\mathrm{O}$ conjunto da diagramação revela o tom de otimismo que não se restringe ao âmbito de aspirações privadas, indicando ainda o crescimento do PIB no continente latino americano e a previsão para o incremento da produção de barris de petróleo na Petrobrás, objetivando alcançar a meta de $640 \mathrm{mil}$ barris por dia. ${ }^{1}$ Mesmo que o título da matéria destacada na capa do jornal sugira uma esperança que teima em resistir, parece também informar e conformar um clima de cautelosa expectativa diante das possibilidades do futuro imediato. A atenção concentrava-se, com nuances e níveis de intensidade distintos, na proximidade com a eleição indireta para presidente e, consequentemente, na restauração de uma normalidade institucional no país. Ou, de maneira mais genérica, na superação do militarismo vigente nas décadas anteriores por meio da eleição de um presidente civil.

No dia 2 de janeiro de 1985, o jornal O Globo, além das referências aos festejos da virada do ano em Copacabana, noticiava o reescalonamento da dívida externa brasileira e o "destino democrático" dos imóveis utilizados por ministros na capital federal. ${ }^{2} \mathrm{~A}$ expectativa cautelosa, que conforma os afetos e desejos de meados da década, parece engendrar uma espécie de alteração do humor coletivo, fazendo com que o futuro se tornasse disponível e pudesse sugerir algo diferente do presente. Os tradicionais votos de "feliz ano novo" ganham um significado menos protocolar, já que expressam a esperança de superação dos anos difíceis que se acumularam nas duas décadas anteriores.

Na Ilustrada da Folha de S. Paulo, de 2 de janeiro de 1985, Osvaldo Peralva escreve, em artigo intitulado "Feliz ano novo, a sério", sobre a substituição do profundo desespero que teria marcado a sociedade ao longo do regime militar por uma crescente esperança no alvorecer do ano. ${ }^{3}$ A própria ideia de superação de um profundo desespero que teria marcado os anos anteriores já sugere um esforço de construção de um novo sentido para a memória do regime que estava prestes a acabar, não somente reconfigurando o passado recente, como também investindo na ampliação das possibilidades 
advindas do futuro. Tarso de Castro, em "Sobre o Ano Novo", também na Folha de S. Paulo, relembrava as angústias derivadas do golpe de 1964 e desejava um "feliz anos novos", servindo como um "feliz ano de 1985! Adeus ano velho de 64, 65, 66, 67, 68, 69, 70, $71,72,73,74,75,76,77,78,79,80,81,82,83,84$ ". ${ }^{4} \mathrm{O}$ anúncio de um recomeço que deixasse para trás a insegurança do passado que ainda se fazia presente funcionava como promessa de dias melhores e como processo de rearticulação de passado, presente e futuro.

$\mathrm{O}$ teor de esperança comedida, que marca de maneira hegemônica os principais jornais do país, parecia inverter a fórmula do livro que se mantinha como o mais vendido no início de 1985, a saber, Feliz Ano Velho. Publicado por Marcelo Rubens Paiva em 1982, posteriormente se tornaria peça teatral e filme; dialogava com a frustração e as incertezas de uma geração que começava a vida adulta na década de 1980, convivendo, ao mesmo tempo, com a manutenção da força repressiva dos militares e com a tentativa de esboçar um "destino democrático" para o país. O livro talvez tenha se tornado um sucesso de público não somente por relatar o momento crepuscular relativo à experiência de uma juventude universitária - descrevendo anseios, frustrações e descobertas de um grupo de jovens que compartilhou o flerte com a arte e com novas formas de sociabilidade -, mas também pela tessitura de uma atmosfera pautada no medo de que o ano seguinte pudesse ser pior do que o anterior. Os receios com o tempo e a frustração constituem elementos fulcrais na própria experiência do autor. Cumpre notar que, quando escreve seu romance de traço autobiográfico, experimentava a sensação de um ontem que ainda não passara e de um amanhã ainda por vir, intensificada pelo enfrentamento dos anos imediatos ao acidente que o tornou cadeirante e pelo desconhecimento do paradeiro do seu pai, o deputado Rubens Paiva, dado como desaparecido pela ditadura militar. ${ }^{5}$

A substituição do Feliz Ano Velho, que impõe a continuidade e o pessimismo, pelo "feliz ano novo", que prevê expectativas palpáveis de mudança, pode configurar, portanto, certa alteração da sensibilidade sobre o tempo, uma espécie de clima de conciliação nacional com o futuro. Desse modo, considerando a hipótese de uma atmosfera de conciliação com o futuro, talvez não seja equivocado 
dizer que a década de 1980 caracteriza-se pelo incessante jogo entre esperança e frustração, extrapolando a própria cronologia formal.

A eleição de Ernesto Geisel (1974-1979) demarca o fortalecimento de um projeto de distensão política, exemplificado principalmente pela revogação do AI-5, mas que se intensificou durante o mandato de João Baptista Figueiredo (1979-1985), sobretudo com a livre organização partidária e a lei de anistia (GASPARI, 2003; FICO, 2013; REIS, 2000). No entanto, ao contrário de mudanças aceleradas que pudessem corresponder às expectativas de grupos sociais organizados, notava-se a lentidão e a incompletude do processo de distensão/redemocratização, tornando latente a repressão do período militar e fragilizando a crença advinda de uma ação política orientada. Mesclavam-se nesse ambiente tanto a memória da repressão passada e ainda presente, quanto a sensação de ineficiência das mobilizações contra o autoritarismo que se mantinha vigente. A debilidade das estruturas legais de feição democrática estorvava o longo caminho da abertura política, pois as mudanças que se anunciavam como desejo majoritário seguiam o compasso ditado pelos militares, os quais mantiveram o controle de todo o processo de abertura gradual e segura (GASPARI, 2003; FICO, 2013).

$\mathrm{O}$ vagaroso processo de desmantelamento do aparato repressivo, portanto, não sugere a superação imediata das práticas de violência e nem mesmo a retomada da capacidade de projetar o futuro político, econômico e social da nação, segundo a articulação de uma vontade geral. Antes da sensação de ruptura e superação do passado, o que parece estar em jogo é certo efeito de latência que marca a temporalidade ao longo da década de 1980, determinando um contexto afetivo no qual o passado ainda se encontra presente. Hans Ulrich Gumbrecht descreve o efeito de latência como uma disposição geral, um clima experimentado de modo subjetivo e maximamente compartilhado. Em outras palavras, o efeito de latência pressupõe a simultaneidade da sensação de congestão e de um movimento que aponta para o futuro (GUMBRECHT, 2014b). $\mathrm{O}$ efeito de latência, portanto, nos sugere o compartilhamento de experiências histórico-afetivas e uma específica sensibilidade sobre o tempo que não descarta a tensão e as intercessões entre a dimensão 
privada e pública dos indivíduos. Desse modo, o descompasso entre vontades coletivas e individuais e a lentidão no processo de distensão/redemocratização alargava o presente, tornando-o repleto de passados, assim como esvaziava as projeções de futuro, tornando-o vazio ou distante.

A derrota de 25 de abril de 1984 na votação da Emenda Dante de Oliveira, definida pela estratégica ausência organizada pelo PDS e provocando frustração diante da mobilização nacional em torno das Diretas Já, não foi capaz de eclipsar de todo as possibilidades de superação do passado. A esperança parece ter sido deslocada para a expectativa da eleição, mesmo que indireta, de Tancredo Neves. $\mathrm{O}$ intermitente esforço de deslocamento das esperanças, além de pragmático e realista, reconfigura os significados de futuro; as expectativas se transformam segundo os avanços e recuos da redemocratização inacabada. $\mathrm{O}$ futuro, desse modo, comporta novas semânticas enquanto depositário hegemônico das esperanças.

Em artigo que demonstra a centralidade da frustração na experiência de distensão/redemocratização, Carlos Fico aponta para uma peculiar e angustiante relação entre passado e futuro. Segundo Fico, "como uma espécie de contrafação de uma ruptura que não houve e da impunidade dos militares, a elite política e os meios de comunicação propagandearam a existência de uma "Nova República", a partir de 1985 [...]". Ainda segundo o autor, a apropriação de símbolos da campanha pelas eleições diretas e a apropriação política da emotividade derivada da morte de Tancredo Neves, marcariam a entrada do país numa fase de suspensão, onde o passado se mantinha no presente (FICO, 2013, p. 247).

Concomitante ao clima de suspensão nacional, em janeiro de 1985, inaugurou-se a exposição "Visual do Rock" no Museu de Arte Moderna do Rio de Janeiro. Alexandre Martins, seu organizador, justifica em matéria do Segundo Caderno do jornal O Globo a relevância da exposição, dizendo que "a cidade inteira está respirando este clima de rock". ${ }^{6}$ A cidade preparava-se para o primeiro Rock in Rio e, ao mesmo tempo, aguardava a realização da eleição indireta para presidente, que ocorreria em 15 de janeiro. ${ }^{7} \mathrm{O}$ pop rock nacional, em suas diferentes propostas e sonoridades, vivia 
seu processo de autonomização e tornava-se importante expressão da cultura de massa. Na atmosfera específica de tentativa de superação do passado, a emergência do pop rock nacional canalizou certos anseios e algumas frustrações da juventude. Nesse momento, segundo o trocadilho de Gilberto Gil: "o rock deu uma blitz na MPB". ${ }^{8}$ Trata-se, aqui, de enfatizar a capacidade do rock nacional de ampliar o público consumidor e ocupar um lugar de destaque nos meios de comunicação no decorrer da década (ALEXANDRE, 2013; MAGI, 2013).

Em “Anos 80”, música do álbum Abre-te Sésamo (1980), Raul Seixas sugere uma imagem que pode ser profícua para o argumento do tempo que se move lentamente, reforçando a noção de que a vontade de mudança não será plenamente satisfeita ao longo da década. Segundo Raul Seixas, a década de 1980 seria como uma "charrete sem condutor", na qual a miséria social e a ação ainda ativa da censura provocariam uma mistura de "melancolia e promessas de amor”. A cena, se colocada em movimento, parece sugerir um provável descarrilamento do país provocado pela indefinição da trajetória e do lugar de chegada. As promessas de amor se perderiam em palavras e na melancolia dos dias que se faziam iguais, assim como na incompletude da ação.

O movimento arrastado do tempo independe dos desejos dos indivíduos, parecendo alheio aos afetos que mobilizam politicamente as projeções hegemônicas de futuro. Ou seja, busca-se aqui uma intermediação entre o circuito dos afetos que orientam a ação política, permitindo adesão social, e a descrição de uma atmosfera melancólica que resulta da latência. De acordo com Vladimir Safatle, a dimensão estrutural profunda que aproxima medo e esperança depende da forma de temporalidade dominada pela expectativa. Além disso, se cada corpo tem seu regime de temporalidade, regimes de temporalidade idênticos podem aproximar corpos aparentemente distantes (SAFATLE, 2016, p. 20). Sem o intuito de corroborar a ideia de uma década perdida, minimizando mobilizações e conquistas sociais, pretende-se aqui destacar o jogo frustração/esperança numa temporalidade pautada pela expectativa, implicando o reconhecimento de certa desorientação do período, articulando promessas não cumpridas e uma ambiência melancólica. 


\section{“A mudança levou tempo por ser tão veloz": o futuro como diferença}

A formação da banda brasilense Legião Urbana (1982-1996), em meados de 1982, ocorre num período em que o rock nacional conquistava significativa projeção no mercado fonográfico. Inicialmente, a Legião Urbana foi formada pelo núcleo Marcelo Bonfá (bateria) e Renato Russo (baixo e vocal) e pretendia fazer uma espécie de rodízio na guitarra como forma de diversificar a sonoridade da banda. Dadas as dificuldades de executar tal proposta, por conta da formação concomitante de diferentes bandas no contexto de Brasília, e após breves passagens de Eduardo Paraná, Ico Ouro Preto (guitarra) e Paulo Paulista (teclado), assume permanentemente a guitarra, em março de 1983, Dado Villa-Lobos - apresentando como currículo a possibilidade de fazer um som tipo Talking Heads (1975-1991). O histórico show realizado no Circo Voador (RJ), em 1985, demarca o início da projeção nacional da banda e prepara caminho para a gravação do primeiro álbum com a entrada de Renato Rocha no baixo. Tal configuração perduraria até o terceiro álbum da banda. (MARCELO, 2012; VILLA-LOBOS; DEMIER; MATTOS, 2015). A trajetória poética da Legião Urbana, entre meados da década de 1980 e início da década de 1990, descontada sua peculiaridade estética, dialoga com um cenário amplo que abarcava a suspensão histórico-política da distensão/abertura e a seminal influência do punk inglês na formatação da atitude e da expressão musical do rock feito em Brasília (ALEXANDRE, 2013).

Qualquer esforço de aproximação da poética da Legião Urbana com a atmosfera histórico-afetiva da década de 1980 pode parecer redundante diante da crueza que reverbera a influência da atitude e da sonoridade punk, ambas pautadas no lema do it yourself. No entanto, a simplicidade das músicas, restritas a poucos acordes, não limita a capacidade de ecoar a experiência urbana da juventude e uma sensibilidade específica em relação ao tempo. O que parece estar em jogo na poética da Legião Urbana não é somente uma espécie de reflexo da dimensão comportamental em consonância com as possibilidades advindas do longo processo de distensão e abertura política, mas, sobretudo, a descrição do stimmung do tempo. 
Trata-se da possibilidade de descrição de uma conjuntura sentimental específica, uma atmosfera histórico-sentimental conformada na percepção do ritmo temporal. Em outras palavras, pretende-se destacar o componente sensível da experiência do tempo, um ler e ouvir com a atenção voltada ao stimmung, objetivando a percepção de sensações interiores que conformam o desejo não satisfeito de ruptura com o passado (GUMBRECHT, 2014a, p. 14).

Explorar o stimmung enquanto categoria universal, tal como pretende Gumbrecht, permite-nos, por meio de um corpo a corpo com a poética da Legião Urbana, tracejar uma estética da melancolia. Melancolia não como signo da genialidade ou do temperamento inconstante relacionado à bile negra, ou, ainda, como patologia relacionada ao desequilíbrio de humores (ARISTÓTELES, 1998; PIGEAUD, 2009), mas, sim, como registro da temporalidade. Uma estética melancólica derivada da constatação de que o presente se manifesta como passado alargado e o futuro como repetição ou impossibilidade.

A recorrência da temática do passado que avança no presente e impossibilita o futuro como diferença tem como corolário, em última instância, a redução de um horizonte de expectativa. $\mathrm{O}$ passado, portanto, não é qualificado somente como entulho autoritário ou como resquício pontual, mas ele também se manifesta na delimitação das expectativas de futuro e no agenciamento de afetos diante da permanência. A atmosfera melancólica deriva tanto do cerceamento do futuro quanto da sensação de que o tempo parece não passar. Em outras palavras, a minimização do horizonte futuro e a impressão de um tempo moroso e repleto de passado têm como consequência o sentimento melancólico. Talvez não seja equivocado dizer que uma possibilidade de solução estética para a abertura do futuro seja sua formatação irônica: a sugestão ou descrição do futuro emergindo como estratégia para denegá-lo. Desse modo, além da negação do futuro evocada pelo no future do movimento punk inglês, o futuro também pode ser negado por meio de sua formulação irônica na poética da Legião Urbana.

No refrão de "Será", música de abertura do álbum de estreia da Legião Urbana (1985)', Renato Russo indaga sobre as possibilidades 
de mudança e as consequências da ação: "Será que nada vai acontecer? Será que é tudo isso em vão? Será que vamos conseguir vencer?” A tensão entre uma dimensão íntima e os aspectos mais gerais da vivência política contemporânea perpassa inúmeras letras da Legião Urbana. Desenham-se nesse jogo deliberado entre interioridade e exterioridade as pretensões existenciais e políticas que motivam a poética da banda, sobretudo de Renato Russo - o próprio revezamento entre primeira pessoa do singular e primeira pessoa do plural demonstra tal tensão no âmbito da forma. Em "Será", o uso repetido de interrogações parece potencializar as dúvidas do ambiente político, econômico e social do país. O processo de redemocratização engendrava expectativas e convocava à ação, parecendo a um só tempo uma tentativa de ampliação do horizonte de expectativa e a intensificação do espaço de experiência. Da vontade de urgência engendrada em atmosfera melancólica são reconhecidos afetos e suas ambivalências políticas, descrevendo um movimento pendular, intenso e oneroso entre esperança e frustração.

A dubiedade que intensifica a sensação melancólica é fruto da incerteza sobre a possibilidade de algo acontecer que seja capaz de imputar a diferença como registro da temporalidade. O tempo de espera acaba conformando a temporalidade na expectativa. $\mathrm{O}$ pachorrento passado-presente que se costura na expectativa da completude do processo de redemocratização enfatiza a desconfiança sobre a efetividade da ação e torna a frustração um sentimento recorrente. Tendo em vista o desejo de ruptura que condiciona a experiência temporal descrita em significativos exemplos de músicas da Legião Urbana e, como extensão, de uma parte significativa daquela geração de jovens, não me parece aleatória a escolha de "Será" como abertura do primeiro álbum.

Em outro fragmento poético, a noção de continuidade pode ser entendida também como uma falsa modernidade. "A dança", música também do primeiro álbum da banda, além da crítica ao sexismo e ao machismo, descreve de maneira irônica uma espécie de modernidade de superfície e a imobilidade do tempo. Trata-se de uma primeira indicação do verniz de modernidade que marca a discrepância entre realidade e discurso, opondo-se à expectativa 
da modernidade sempre postergada. Vejamos um trecho da canção: "Você é tão moderno/Se acha tão moderno/Mas é igual a seus pais/É só questão de idade/Passando dessa fase/Tanto fez e tanto faz".

A questão geracional, enquanto organizadora do descontentamento com o normativo, corrobora a tentativa de descrição de certa experiência do tempo. "Geração Coca-Cola" articula-se na denúncia da precariedade da modernização nacional e, por conseguinte, no modo irônico. Ao transformar os filhos da revolução no futuro da nação, ironiza o futuro que não serve como realização daquilo que se esperava de parte dos jovens de classe média com acesso à educação formal, mas como seu avesso, a saber, a possibilidade de "fazer comédia no cinema com as suas leis". A falência de certo projeto de formação, segundo os padrões de uma modernização conservadora do país ${ }^{10}$, está contida na transgressão irônica, no ato de "cuspir de volta o lixo em cima". O que está insinuado, portanto, é uma espécie de revide geracional que denega as expectativas engendradas no passado ou, em outras palavras, a emergência de uma cultura jovem que se opõe às promessas contidas no projeto de futuro formulado pelos militares.

"O Reggae" - que, de acordo com o controle que a banda detinha sobre as suas escolhas artísticas, não por acaso, sucede "Geração Coca-Cola" - desenvolve-se como complemento da crítica à modernidade superficial e de traço conservador da ditadura militar. O controle do destino e o cumprimento inevitável das ordens são seguidos pela promessa de revide que finaliza os versos e reforça a vontade de ruptura.

Beberam o meu sangue e não me deixam viver Têm o meu destino pronto e não me deixam escolher Vêm falar de liberdade pra depois me prender Pedem identidade pra depois me bater

Tiram todas as minhas armas

Como posso me defender? Vocês venceram esta batalha

Quanto à guerra, vamos ver.

(LEGIÃO URBANA, 1985) 
O primeiro álbum termina com "Por enquanto". A voz grave e a textura do teclado dialogam com a noção de permanência que orienta, em grande medida, a letra da música, além de ecoar a influência pós-punk do Joy Division (1976-1980). O jogo antitético entre permanência e mudança indica o desamparo proveniente da experiência de perda das antigas certezas. No entanto, pôr as certezas em xeque não torna necessariamente o tempo protagonista da transformação, pelo contrário, mantém-no como referência de mais do mesmo. "Mudaram as estações/E nada mudou/Mas eu sei que alguma coisa aconteceu/Está tudo assim tão diferente/Se lembra quando a gente chegou um dia a acreditar/Que tudo era pra sempre/ Sem saber/Que o pra sempre/Sempre acaba? ” O retorno para casa como desfecho implica essa dimensão nostálgica relativa à perda de certezas. Contudo, o traço nostálgico não seria um elogio ao passado histórico como um todo, mas àqueles sentimentos e àquelas sensações que pautam a infância e que provocam o descolamento da realidade. ${ }^{11} \mathrm{~A}$ perda lamentada é da inocência, daquilo que se acreditava antes - no encarte contido no vinil, o "sempre acaba" é seguido de um ponto de interrogação que parece ter sido suprimido posteriormente.

O segundo álbum da Legião Urbana, Dois $(1986)^{12}$, parece ainda mais intenso na ideia da ação que se mantém em suspenso e da limitação do futuro que provoca a sensação de melancolia. ${ }^{13}$ A diferença de sonoridade, com a inclusão de violões e o lirismo das letras, indicam novos caminhos para estética melancólica das músicas. Pode-se dizer que a indecisão ganha tons mais intimistas no violão e nos versos de "Quase sem querer", quando o eu lírico diz: "Tenho andado distraído/ impaciente e indeciso/ E ainda estou confuso/ Só que agora é diferente:/Estou tão tranquilo/ E tão contente". No entanto, por conta da maciça execução da balada folk "Eduardo e Mônica" e talvez do efêmero otimismo do Plano Cruzado, o álbum acabou obtendo uma recepção hegemônica que imprimia certa leveza, permitindo o reconhecimento da maturidade e de um clima mais arejado na sonoridade da banda. Em oposição à suposta leveza, "Andrea Doria" se constrói no diálogo que expõe as dificuldades do idealista que desejava "fazer floresta do deserto" e "diamantes de pedaços de vidro", porém não encontrando solução 
no âmbito da mudança da realidade. $\mathrm{Na}$ verdade, o próprio diálogo serviria como meio pacificador das angústias advindas do estar no mundo. A melancolia organiza também a pintura inventada em "Acrilic On Canvas", tracejando o que não aconteceu e relatando promessas nunca feitas, a suspensão da ação e as incertezas continuam orientando a poética da banda.

A sensação do tempo que se esvai sem anunciar a diferença garante a manutenção da melancolia. Não somente por não ter "mais o tempo que passou", mas como projeções de um futuro à deriva. Em "Indios", por exemplo, nota-se a utilização do pretérito mais-que-perfeito ("quem me dera") e sua repetição ao longo da melodia ecoando a ideia de perda de possibilidade do futuro passado. Vejamos a estrutura do lamento: "Quem me dera ao menos uma vez/ Explicar o que ninguém consegue entender/Que o que aconteceu ainda está por vir/E o futuro não é mais como era antigamente”.

A fatalidade daquilo que aconteceu e o cerceamento da utopia passada, daquilo que poderia ter sido, provoca a tensão ao longo da música. Por isso a necessidade paradoxal de "insistir nessa saudade que eu sinto/ De tudo que eu ainda não vi”. O paradoxo, de uso recorrente nas composições da banda, funciona como indicativo da saudade do desconhecido, reforçando a perda de referência do passado e futuro. O olhar que ressalta perdas se depreende da perspectiva indígena, do efeito de estranhamento diante dos caminhos trilhados e dos futuros não previstos no passado. Desse modo, o futuro não somente não estava contido nas expectativas engendradas pela experiência do passado, como também se apresenta em uma situação de decrepitude, provocando, em última instância, saudade daquilo nunca visto. $\mathrm{O}$ "mundo doente" refletido no espelho, portanto, remete tanto à decadência em seu aspecto material, como à miséria identificada na ganância do passado e no presente nacional, além de representar possibilidade de autocrítica das estruturas sociais hegemônicas. Seria justamente tal dimensão crítico-reflexiva que impediria a possibilidade de comoção através do choro, de mover-se conjuntamente compartilhando aquela angústia, de inserir-se conjuntamente ou mesmo individualmente naquilo que causa desconforto. O desfecho melancólico e irônico está na disparidade 
entre o desejo expresso ao longo da música de "ao menos uma vez" fazer o contrário daquilo que foi feito efetivamente ou, ainda, na não concretização de futuros passados.

No terceiro álbum da banda, intitulado Que país é este: 1978/1987 14 (1987), foram reunidas músicas escritas no final da década de 1970 e início da seguinte. Portanto, enquadra-se em sonoridade e temáticas mais próximas do primeiro álbum. No texto de apresentação, contido no encarte do vinil, a banda indica que o álbum registra uma ingenuidade perdida. Segundo o texto, a esperança era de que o "país iria crescer e mudar para melhor e todos acreditaram". Ainda de acordo com as palavras impressas no encarte: "Até aí morreu Neves (trocadilho imperdoável, mas necessário) e cantar que 'temos todo tempo do mundo', porque 'somos tão jovens' lembra um tempo distante, um tempo perdido mesmo" ${ }^{15}$. Bastante significativo é o fato de que, ao retratar aquelas sensações advindas da experiência da juventude urbana e de certa inocência perdida, o álbum tenha recebido o selo de interdição de execução pública e radiodifusão de "Faroeste Caboclo" e "Conexão Amazônica", o que confere materialidade à noção de permanência ${ }^{16}$. "Mais do mesmo", uma das poucas músicas que não foram feitas no período do Aborto Elétrico (1978-81), antes da formação da Legião Urbana, ou seja, que foi composta provavelmente entre 1986 e 1987, além de captar o sentimento de inadequação juvenil, indica de maneira direta o lugar reservado à esperança: "Em vez de luz tem tiroteio no fim do túnel/Sempre mais do mesmo/Não era isso que você queria ouvir?”. A melancolia permanece enquanto marca das esperanças frustradas e na negativação do futuro que torna plausível a gravação de músicas antes esquecidas no repertório, demasiadamente datadas para serem registradas em disco.

A sensação de permanência ou a percepção de um futuro do passado ainda violento e aquém das expectativas garantia a atualidade do repertório, dialogando com a atmosfera de desassossego que ainda vigorava no país. A esperança de que as músicas se tornassem datadas não se concretiza; a certeza da atualidade de músicas escritas há quase dez anos corrobora a percepção de um tempo vagaroso. A presença do passado garantia uma espécie de cruzamento de 
tempos distintos. A sincronia de temporalidades não derivava de um esforço de resgate nostálgico, mas do compartilhamento de uma atmosfera histórico-afetiva.

Mesmo "Angra dos Reis", composta também provavelmente entre 1986 e 1987 para complementar o antigo repertório, dialoga com a ideia de que "todos os dias são iguais". Além disso, "Angra dos Reis" parece reproduzir o temor de um futuro catastrófico, quando questiona: "Por que se explicar se não existe perigo?". A proximidade com o acidente nuclear de Tchernóbil e com o acidente com Césio-137 em Goiânia repercute na descrição do cotidiano de uma região constantemente ameaçada. ${ }^{17}$ Chegando mesmo a descrever a situação de catástrofe: "Mesmo se as estrelas começassem a cair/E a luz queimasse tudo ao redor/E fosse o fim chegando cedo/E você visse o nosso corpo em chamas”, finalizando com outra indagação sobre a quase impotência para uma reação efetiva: "Quando as estrelas começassem a cair/Me diz, me diz pra onde a gente vai fugir?".

O quarto álbum lançado pela Legião Urbana, intitulado $A s$ Quatro Estações (1989) ${ }^{18}$, sinaliza um salto lírico ainda mais intenso que aquele dado em Dois. As letras, no geral, são destituídas de referências temporais explícitas, dificultando sua datação ou sua audição como mero retrato de uma época. Com exceção de "Feedback song for a dying Friend", todas as músicas tornaram-se "hit-singles" com intensa difusão em rádio. As músicas pareciam indicar um momento mais ensolarado da banda, sobretudo, pelas referências místicas e religiosas que evocavam um caminho em direção à interioridade. Segundo Renato Russo, havia uma esperança depositada na espiritualidade que amalgamava o álbum. ${ }^{19}$ Se, por um lado a espiritualidade poderia servir como orientação individual de certos pressupostos éticos e morais, por outro poderia indicar o sentimento de frustração pela impossibilidade de mudança da realidade. Tal constatação torna-se viável na percepção da ausência de coragem para a transformação: “até bem pouco tempo atrás/Poderíamos mudar o mundo/Quem roubou nossa coragem?".

Em "Há tempos", os primeiros versos confirmam a sensibilidade melancólica que conformam a poética da banda: "Parece cocaína mas é só tristeza, talvez tua cidade/Muitos temores nascem 
do cansaço e da solidão/ Descompasso, desperdício/ Herdeiros são agora da virtude que perdemos/ Há tempos tive um sonho/ Não me lembro, não me lembro". O descompasso como herdeiro das virtudes perdidas implica o desamparo e a desorientação. Parece não haver possibilidade de segurança para além de uma dimensão espiritual; a sensação de desamparo não provocaria um mover-se para fora, um descentramento do indivíduo, pelo contrário, implicaria um investimento ainda mais intenso na interiorização. As incertezas do mundo exterior não garantem segurança, pois "só o acaso estende os braços/a quem procura abrigo e proteção”.

Em 1965 (Duas tribos), a temática da repressão do período ditatorial é retomada como reação a certa nostalgia em relação à estabilidade e segurança do período - vale mencionar que a nostalgia da segurança dos militares reforça as incertezas e aflições da década de 1980. A letra faz referência direta à tortura. No entanto, a dicotomia entre o bem e o mal, que pode ser cantada como a certeza de estar do lado correto, "com a luz e com os anjos", opera no registro da ironia. Ressalta-se na dicotomia o discurso ufanista e otimista da ditadura militar, estimulando a ingênua nostalgia da repressão que ainda se fazia latente. ${ }^{20}$ Os questionamentos seguem a lógica da deturpação da experiência e do distanciamento de discurso e realidade: "Quando querem transformar/Dignidade em doença? Quando querem transformar/Inteligência em traição? Quando querem transformar/Estupidez em recompensa? Quando querem transformar/Esperança em maldição?”. Para em seguida exporem a bipolaridade simplista e maniqueísta da propaganda: "É o bem contra o mal/E você de que lado está? Estou do lado do bem/E você de que lado está? Estou do lado do bem/Com a luz e com os anjos".

Se o registro irônico busca desvelar a disparidade entre discurso e realidade, também pode ser encontrado na projeção de futuro. Assim, torna-se patente que a abordagem poética sobre a repressão nos tempos da ditadura, entrecortada pelo discurso ufanista do progresso nacional, tende a provocar um efeito de otimismo por conta do andamento da melodia e da explosão do falso refrão. Vejamos as duas estrofes finais: 


\author{
Mataram um menino \\ Tinha arma de verdade \\ Tinha arma nenhuma \\ Tinha arma de brinquedo \\ Eu tenho autorama \\ Eu tenho Hanna-Barbera \\ Eu tenho pera, uva e maçã \\ Eu tenho Guanabara \\ E modelos revell \\ O Brasil é o país do futuro \\ O Brasil é o país do futuro \\ O Brasil é o país do futuro \\ O Brasil é o país \\ Em toda e qualquer situação \\ Eu quero tudo pra cima \\ Pra cima, pra cima.
}

(LEGIÃO URBANA, 1989).

A referência aos bens advindos de uma modernização restrita potencializa a crítica irônica da música. Se a violência da morte de um menino que poderia estar assaltando com uma arma de brinquedo toca no tema da desigualdade social, relatando o acesso vedado aos bens da modernidade por determinados segmentos sociais; por outro lado, a classe média, por meio do consumo de modelos Revell ou dos desenhos animados da dupla norte-americana William Hanna e Joseph Barbera, vivenciaria de maneira eufórica suas aquisições do presente e expectativas de futuro. A falsa alegria do canto relaciona-se com a proposta de uma perspectiva comparada da experiência histórico-afetiva, através da qual seria possível contrapor à década de 1980, com suas frustrações a anseios, e às utopias eclipsadas pela ditadura militar. Assim, o que se pretende destacar aqui é justamente a carência permanente do presente e a desconfiança no futuro que se expressa na trajetória poética da Legião Urbana. A angustiante ausência de novos projetos organiza 
a sensibilidade do tempo. Mais forte do que a postura de transformação da realidade social é a frustração diante da quase inevitável sensação de imobilidade.

\section{"Este é o nosso mundo": o equilíbrio da rotina e um copo d'água}

O esvaziamento do futuro e a melancolia, ambos organizadores de afetos e da sensibilidade do tempo, continuam orientando a poética da Legião Urbana, podendo inferir-se, inclusive, certo espraiamento da atmosfera da década de 1980 nos anos iniciais da década seguinte. A mobilização de expectativas na eleição presidencial de 1989, primeira oportunidade de toda uma geração de votar para presidente, provocou grande investimento político e afetivo num recomeço ou numa mudança sensível. $\mathrm{O}$ fato de poder eleger diretamente um presidente da República tinha enorme relevância para o humor geral da nação, celebrando a retomada de um direito tolhido ao longo da ditadura e mesmo em seus estertores. Na eleição de 1989, havia um amplo arco ideológico de candidatos; no entanto, para além de uma narrativa eleitoral, pretende-se chamar a atenção, mais uma vez, para o jogo entre esperança e frustração.

Não se pode dizer que a relação entre esperança e frustração seja uma característica específica da temporalidade da década de 1980 e início da década seguinte. A mobilização desses afetos conforma a experiência política moderna, contudo, na década de 1980 a velocidade com que o pêndulo se move parece provocar uma frustração estendida, somente alterada por breves sopros de esperança. Não parece correto, portanto, pressupor uma postura cínica diante dos eventos histórico-políticos, mantendo certo grau de desconfiança superior em relação ao lento correr do tempo. A mobilização político-afetiva e os discursos que embalam a disputa eleitoral ecoavam, amiúde, o novo e o velho, o atraso e a modernização, o passado e o futuro. O quadro eleitoral derivado da tensão armada pelos usos de categorias temporais pode corroborar o argumento de que a melancolia derivava da angústia de um tempo 
estático e incapaz de enunciar a diferença. A contraposição entre a crise do socialismo soviético e a retórica da gestão modernizadora neoliberal exemplifica o jogo entre passado e futuro na linguagem política. Em outras palavras, a polarização que marcou o segundo turno da eleição presidencial de 1989 armava-se entre uma supostamente velha esquerda, representada pela candidatura de Luiz Inácio Lula da Silva, e a alternativa da nova política de Fernando Collor de Mello. Ao longo da campanha, a linguagem mobilizada pelos candidatos, antes de viabilizar o debate franco de projetos, transitava numa semântica temporal; a linguagem política articulava-se em narrativas que buscavam atribuir sentido para a experiência histórica recente e anunciar possíveis futuros.

A vitória de Fernando Collor de Mello, filiado a um partido com pouca expressão nacional, Partido da Reconstrução Nacional (PRN), assim como sua posse em março de 1990, parece servir como uma espécie de prolongamento da década de 1980. Não somente pelo uso de categorias temporais - no geral, sempre mobilizadas com maior ou menor intensidade nas disputas eleitorais -, mas pela manutenção de um quadro inflacionário que corroía os salários, além do confisco das poupanças e da instabilidade política, resultando numa frágil aliança parlamentar e em um governo cercado por denúncias de corrupção.

Foi exatamente nessa atmosfera de desenganos e incertezas que a Legião Urbana lança seu quinto álbum ${ }^{21}$, fazendo, deliberada e declaradamente, seu álbum mais melancólico até então ${ }^{22}$. Na música "O teatro dos vampiros", o desengano e a noção de permanência do passado são bastante evidentes: "Vamos sair - mas não temos mais dinheiro/Os meus amigos todos estão procurando emprego/ Voltamos a viver como há dez anos atrás/E a cada hora que passa/ Envelhecemos dez semanas". Talvez o "voltamos", no trecho destacado, seja antes uma referência ao movimento pendular esperança-frustração do que uma referência ao retorno a uma situação específica de estabilidade que fora gradativamente sendo perdida. A sensação da efemeridade das expectativas está expressa, uma vez mais, na incapacidade de efetivação do movimento de superação do passado: seja na mobilização por eleição direta para presidente e sua derrota no Congresso, seja na eleição indireta de Tancredo Neves e sua morte em seguida, seja na estabilidade superficial e eleitoreira 
do Plano Cruzado ou ainda na esperança depositada no pleito de 1989 e na imediata frustração provocada pelo Plano Collor.

Se o fio de esperança que se apresentava em As quatro estações era a dimensão espiritual, pressupondo certo alheamento do mundo e busca por refúgio na interioridade, no álbum $V$ (1991), a possibilidade de alívio está depositada no âmbito privado, em relacionamentos interpessoais, na amizade e no amor que ganha contornos no cotidiano e no compartilhamento de experiências. Antes, a promessa de amor mantinha-se em suspenso, anunciada em dicção camoniana através da tensão advinda de seus paradoxos, ou, ainda, em tons bíblicos que idealizavam suas possibilidades de realização ecumênicas. No entanto, nota-se agora a inflexão poética que conduz os sentimentos de amor e amizade para uma dimensão mais ordinária da existência, manifestando-se na experiência mais chã, enquanto rotina.

A descrição da rotina em "O mundo anda tão complicado" remete à construção desse universo privado enquanto refúgio: "Gosto de ver você dormir/ Que nem criança com a boca aberta/O telefone chega sexta-feira/Aperta o passo por causa da garoa/Me empresta um par de meias/A gente chega na sessão das dez/Hoje eu acordo ao meio-dia/Amanhã é sua vez”. Em seguida, o refrão expõe a dualidade entre a rua e a casa, o público e o privado: "Vem cá meu bem, que é bom lhe ver/O mundo anda tão complicado/ Que hoje eu quero fazer tudo por você”.

A urgência por ruptura parece ter cedido espaço para o comedimento e o restrito conforto de um ambiente circunscrito. $\mathrm{O}$ refúgio almejado na interioridade que, no limite, acaba esbarrando na solidão, desloca-se para uma experiência equilibrada de amor e amizade. "A montanha mágica", em referência à busca por reabilitação e autoconhecimento, tal qual descrito no romance homônimo de Thomas Mann, mostra-se como relato das dificuldades advindas da dependência química, em que o personagem da canção, lastreado na experiência do próprio letrista, equilibra-se entre dias e noites, entre a suavidade da existência e o mal-estar. ${ }^{23}$ Contudo, a vontade de ter "um dia de sol n'um copo d'água" só parece possível pelo investimento naqueles que o cercam e na existência comezinha, que, antes de projeções de futuro, implica viver com intensidade um dia de cada vez. Assim, demarca-se que fora da dimensão privada da 
vivência só restariam ruínas: "o mecanismo da amizade, a matemática dos amantes - agora só artesanato: o resto são escombros”.

"Metal contra as nuvens" pode ilustrar a mistura de sensações que perpassa a década de 1980 e avança na seguinte. Na segunda parte da música encontra-se referência direta à desesperança e ao engano: "Quase acreditei na sua promessa/E o que vejo é fome e destruição/Perdi a minha sela e a minha espada/Perdi o meu castelo e minha princesa/Quase acreditei/Quase acreditei”. A repetição do "quase" enfatiza o equívoco, o engano de acreditar na transformação, na possibilidade de mudança em futuro próximo. $\mathrm{O}$ círculo temporal traçado tem como ponto de convergência a frustração pelo esfacelamento das projeções de futuro.

\section{Últimos acordes}

A tentativa de identificar uma estética melancólica na poética da Legião Urbana pautou-se na sensibilidade temporal que se expressa no jogo entre esperança e frustração. A perspectiva de uma década perdida torna-se insuficiente para uma compreensão dinâmica dos afetos mobilizados no período de distensão/abertura e nos anos iniciais da Nova República. A ênfase analítica na instabilidade econômica e na hiperinflação desconsidera o investimento político-afetivo no esforço de superação do passado e suas possíveis consequências. A impossibilidade de intervir, ou a ineficácia do gesto, que já estava colocada nos desejos insatisfeitos ao longo da segunda metade de 1980, mantém-se, de maneira bastante significativa, no limiar da década de 1990. A busca pelo equilíbrio dos dias parece emergir enquanto um sopro de experiência, registrada em sua fugacidade, feito breve lufada em uma atmosfera histórico-sentimental que se apresentava quase estática e organizada segundo uma perspectiva melancólica. Mais do que a descrição densa de uma época, os fragmentos-músicas da Legião Urbana sugerem um efeito melancólico advindo do registro da temporalidade, ou seja, uma peculiar recepção e organização sensível do tempo. O desgaste proveniente das oscilações de emoções encaminha um gradativo recolhimento na interioridade e nos afetos costurados corriqueiramente, pois o 
tempo que não passa provoca a angústia de uma atmosfera viciada e alheia aos esforços de produção da diferença. Desse modo, a melancolia derivada da frustração com os descaminhos individuais e coletivos talvez só possa ser remediada, no interior da poética da banda, pelo investimento na experiência intensa no cotidiano. A esperança melancólica de que "tudo passará", parece residir no canto compartilhado:

Tudo passa, tudo passará

E nossa estória não estará pelo avesso

Assim, sem final feliz.

Teremos coisas bonitas para contar

E até lá, vamos viver

Temos muito ainda por fazer

Não olhe para trás

Apenas começamos

O mundo começa agora

Apenas começamos.

(LEGIÃO URBANA, 1991).

\section{SERÁ QUE NADA VAI ACONTECER? TIME AND MELANCHOLY IN LEGIÃO URBANA'S POETICS}

Abstract: Throughout the 1980's Brazilian rock has become an important form of mass culture expression. Not only because of the cultural industry professionalization which enlarged enormously the consumption and circulation, but also and above all, for reverberating distinctive expectations and anguish specifics of that generation. Bearing in mind the movement of autonomization and construction of a peculiar language, the aim of this essay is signalize a kind of sensibility about time outlined in the poetry of the band Legião Urbana between 1985 and 1991. Therefore, this paper is an attempt to articulation time experience and aesthetic of melancholy, sticking to the affections and the game between hope and frustration mobilized in the band's lyrics.

Keywords: Legião Urbana. Temporality. Melancholy. 


\section{Notas}

${ }^{1}$ Folha de S. Paulo. São Paulo, 1 de janeiro de 1985. p. 1. Disponível em: <http:// acervo.folha.uol.com.br/fsp/1985/01/01/2/>. Acesso em: 27 maio 2017.

${ }^{2}$ O Globo. Rio de Janeiro, 2 de janeiro de 1985. p. 1. Disponível em: <http:// acervo.oglobo.globo.com/consulta-ao-acervo/?navegacaoPorData=198019850102>. Acesso em: 10 jun. 2017.

${ }^{3}$ PERALVA, Osvaldo. Feliz ano novo, a sério. Folha de S. Paulo, Ilustrada, 2 de janeiro de 1985. p. 6 Disponível em: <http://acervo.folha.uol.com.br/ fsp/1985/01/02/21/>. Acesso em 27 maio 2017.

${ }^{4}$ CASTRO, Tarso de. Sobre o Ano Novo. Folha de S. Paulo, Ilustrada, 2 de janeiro de 1985. p.2. Disponível em: http://acervo.folha.uol.com.br/fsp/1985/01/02/21/. Acesso em 27 maio 2017.

${ }^{5}$ As circunstâncias da morte do deputado cassado Rubens Beyrodt Paiva foram investigadas na Comissão Nacional da Verdade e detalhadas no relatório final de 2014. Conferir o terceiro volume do relatório sobre mortos e desaparecidos políticos. Disponível em: 〈http://www.cnv.gov.br/>.

${ }^{6}$ Jornal O Globo. Segundo Caderno, p. 3, 3 jan. 1985. Disponível em: <http:// acervo.oglobo.globo.com/consulta-ao-acervo/?navegacaoPorData=198019850103>. Acesso em: 25 maio 2017.

${ }^{7} \mathrm{Na}$ noite de 15 de janeiro de 1985, mesmo dia da eleição indireta de Tancredo Neves, o Barão Vermelho executava "Pro dia nascer feliz" em clima de euforia. Dentre tantos problemas e vaias no primeiro dia do Festival, o refrão da música foi cantado com sentido redobrado. O Brasil parecia estar por um triz de um amanhã feliz.

${ }^{8}$ Sobre a sublimação poética da liberdade e do trauma da repressão recente nas canções de abertura da MPB, demarcando a tensão entre o medo que persistia e da liberdade por conquistar, ver: NAPOLITANO, Marcos. MPB: a trilha sonora da abertura política (1975/1982). Estudos Avançados, São Paulo, v. 24, n. 69, 2010. ${ }^{9}$ LEGIÃO URBANA. Legião Urbana. Rio de Janeiro: EMI-Odeon, 1985. LP. (Lado A: "Será", "A dança", "Petróleo do Futuro", "Ainda é cedo", "Perdidos no espaço", "Geração Coca-Cola”; Lado B: "O Reggae”, "Baader-Meinhof Blues”, "Soldados", "Teorema”, "Por enquanto").

${ }^{10}$ A própria ideia de uma modernização conservadora, em seu aspecto paradoxal e irônico, visa registrar a concomitância do crescimento das forças produtivas e o acirramento da injustiça social durante a ditadura militar, sobretudo, durante o denominado "Milagre econômico". Para uma análise de suas diferentes apropriações, consultar: FICO, Carlos. "Ditadura militar brasileira: aproximações teóricas e historiográficas. Tempo e Argumento, Florianópolis, v. 9, n. 20, p. 5-74, jan./abr. 2017.

Anos 90, Porto Alegre, v. 24, n. 46, p. 45-70, dez. 2017 
${ }^{11}$ Para pensar a nostalgia não somente como deslocamento, mas também como emoção histórica derivada da mudança na concepção de tempo, ver: BOYM, Svetlana. Mal-estar na nostalgia. Tradução de André de Lemos Freixo e Marcelo Santos de Abreu. História da Historiografia, Ouro Preto, n. 23, abr. 2017. p. 154. Ver também: STAROBINSKI, Jean. A tinta da melancolia: uma história cultural da tristeza. São Paulo: Companhia das Letras, 2016.

${ }^{12}$ LEGIÃO URBANA. Dois. Rio de Janeiro: EMI-Odeon, 1986. LP. (Lado 1: "Daniel na Cova dos Leões", "Quase sem querer", "Acrilic on Canvas", "Eduardo e Monica", "Central do Brasil", "Tempo Perdido"; Lado 2: "Metrópole", "Plantas embaixo do aquário", "Música Urbana 2", "Andrea Doria", "Fábrica", "Índios”). ${ }^{13}$ Talvez seja importante lembrar que Renato Russo havia planejado um álbum duplo que seria intitulado Mitologia \& Intuição. "Após vender mais de $100 \mathrm{mil}$ cópias de seu álbum de estreia, Renato pôde se valer de seu sonho rock já na preparação do segundo LP do grupo. 'Ele era um cara que tinha essa percepção pop, do que um disco pode representar para o universo de seu público' lembra Dado Villa-Lobos. 'Tinha essa coisa na cabeça, tecnicamente, até. Sabia como montar um disco, estruturar um LP como se ele contasse uma história'. Renato queria lançar um álbum duplo, a ser batizado de Mitologia \& Intuição. O título era retirado de uma "coleção" que Renato mantinha em sua mente, com Aloha, Disciplina \& Virtude e Roma, entre outras. 'Sempre ponderávamos sobre lançar um disco duplo, mas esbarrávamos em questões econômicas', conta Dado.” ALEXANDRE, Ricardo. Dias de luta: o rock e o Brasil dos anos 80. Porto Alegre: Arquipélago, 2013. p. 284-286. Ainda sobre a proposta de fazer um álbum duplo, ver o capítulo IV do relato de Dado Villa-Lobos: VILLA-LOBOS, Dado; DEMIER, Felipe Abranches; MATTOS, Romulo Costa. Dado Villa-Lobos: memórias de um legionário. Rio de Janeiro: Mauad X, 2015.

${ }^{14}$ LEGIÃO URBANA. Que país é este: 1978/1987. Rio de Janeiro: EMI-Odeon, 1987. LP. (Lado 1: "Que país é este", "Conexão Amazônica”, "Tédio (com um T bem grande pra você)", "Depois do começo", "Química”; Lado 2: "Eu sei”, "Faroeste Caboclo", "Angra dos Reis", "Mais do Mesmo").

${ }^{15}$ Segue o texto completo de apresentação: "Este é um registro da maior parte das canções do Legião Urbana nunca antes lançadas em disco, mas já conhecidas através de apresentações ao vivo e gravações pirata. São nove canções, em versão original de estúdio, que hoje soariam deslocadas. Não há mais inocência e vai-se longe o tempo onde "Que País É Este” era um perigoso grito de rebeldia (1978): hoje resta a lembrança nostálgica de um tempo que dificilmente vai voltar. Era um tempo onde Freud e Jung ainda eram discutidos seriamente em mesa de bar e onde a rota das drogas passava pela Amazônia e somente de lá para os grandes centros. Não se falava abertamente como hoje de tantas coisas, coisas que toda criança sabe hoje em dia, nem pelos jornais. Drummond estava 
vivo, John Lennon e Sid Vicious também. Até aí morreu o Neves (trocadilho imperdoável, mas necessário) e cantar que 'temos todo o tempo do mundo', porque 'somos tão jovens' lembra um tempo distante, um tempo perdido mesmo. Muito mais ainda o inconformismo juvenil, por pura diversão, das canções do grupo Aborto Elétrico, origem de parte do repertório inicial da Legião Urbana, isto já quase cinco anos depois. As letras destas nove canções refletem uma ingenuidade adolescente mas só por terem sido escritas há quase nove anos atrás. A temática continua atual, às vezes até demais. 'Nas favelas, no Senado, sujeira pra todo lado' é de certa forma adolescente e ingênuo mas, depois de uma letra como 'Índios', que trata do mesmo assunto, poderia até ser a mesma música, para onde ir? Há uma diferença de sete anos entre as duas e o que mudou? Parece até que queremos 'vender todas as almas dos nossos índios num leilão’ ainda, do jeito que as coisas vão”. LEGIÃO URBANA. Que País É Este: 1978-1987. Rio de Janeiro: EMI-Odeon. LP, 1987.

${ }^{16}$ A censura moral que orientava a ação do DCDP (Divisão de Censura de Diversões Públicas), executada durantes as décadas de 1970 e 1980, somente seria desativada institucionalmente com a promulgação da Constituição de 1988. Na década de 1980, mesmo com a presença de um civil na presidência da República, são numerosos e significativos os casos de censura, tais como o do filme de Jean-Luc Godard, Je Vous Salue, Marie (1986), sob alegação de ofensa às crenças católicas, e de músicas de bandas como Inocentes e Plebe Rude. Para uma análise da dimensão saneadora e pedagógica da censura moral na década de 1970, ver: MARCELINO, Douglas Attila. Subversivos e pornográficos: censura de livros e diversões públicas nos anos 1970. Rio de Janeiro: Arquivo Nacional, 2011.

${ }^{17} \mathrm{O}$ acidente com Césio-137, ocorrido em setembro de 1987 em Goiânia, provocado pelo descarte inadequado de um aparelho de Radioterapia pelo Instituto Goiano de Radioterapia, contaminou centenas de pessoas. No encarte do álbum, ao comentar a origem de "Tédio (com um T bem grande pra você)", a banda sugere que "os mais modernos podem cantar Césio com um C, se desejarem". Para uma dimensão do impacto do acidente de Tchernóbil e de suas consequências na vida dos envolvidos diretamente, ver: ALEKSIÉVITCH, Svetlana. Vozes de Tchernóbil. São Paulo: Companhia das Letras, 2016.

${ }^{18}$ Legião Urbana. As quatro estações. Rio de Janeiro: EMI-Odeon, 1989. (Lado 1: "Há tempos", "Pais e filhos", "Feedback song for a Dying Friend", "Quando o sol bater na janela do teu quarto", "Eu era um lobisomem juvenil"; Lado 2: "1965 (Duas tribos)", "Monte Castelo", "Maurício", "Meninos e meninas", "Se fiquei esperando meu amor passar").

${ }^{19}$ Ver entrevista concedida ao canal MTV. Disponível em: <https://www.youtube. com/watch? $\mathrm{v}=\mathrm{a} 8 \mathrm{~S} 3 \mathrm{tNW} 3 \mathrm{tY} 8>$. Acessado em: 28 maio 2017.

${ }^{20}$ Sobre o otimismo e propaganda durante a ditadura militar, conferir: FICO, Carlos. Reinventando o otimismo: ditadura, propaganda e imaginário social no Brasil. Rio de Janeiro: FGV, 1997. 
${ }^{21}$ Legião Urbana. V. Rio de Janeiro: EMI-Odeon, 1991. (Lado 1: "Love song (cantiga de amor)", "Metal contra as nuvens", "A ordem dos templários (instrumental)", "A montanha mágica"; Lado 2: "O teatro dos vampiros", "Vento no litoral”, "O mundo anda tão complicado", "Lâge D’or", "Come share my life”). ${ }^{22}$ Nos álbuns posteriores, como O Descobrimento do Brasil (1993), A Tempestade (1996) e Uma outra Estação (1997 - póstumo), a melancolia continua sendo um elemento importante da organização de afetos. No entanto, apesar da manutenção de referências temporais e de ambiência, a melancolia parece derivar de fatores relacionados à própria vivência da banda. A experiência do tempo continua como lugar de angústia, perda e incompreensões, mas a ideia da solidão, do descontrole com a própria vida e da finitude parece ganhar o primeiro plano na poética melancólica da banda e, sobretudo, na perspectiva de Renato Russo.

${ }^{23}$ Para um relato da tentativa de superação da dependência química, ver: RUSSO,

Renato. Só por hoje e para sempre: diário do recomeço. Organização e notas: Leonardo Lichote. São Paulo: Companhia das Letras, 2015.

\section{Referências}

ALEKSIÉVITCH, Svetlana. Vozes de Tchernóbil. São Paulo: Companhia das Letras, 2016.

ALEXANDRE, Ricardo. Dias de luta: o rock e o Brasil dos anos 80. Porto Alegre: Arquipélago, 2013.

ARISTÓTELES. O homem de gênio e a melancolia: o problema XXX, I. Tradução do grego para o francês, apresentação e notas: Jackie Pigeaud. Tradução do francês: Alexei Bueno. Rio de Janeiro: Lacerda, 1998.

BOYM, Svetlana. Mal-estar na nostalgia. Tradução de André de Lemos Freixo e Marcelo Santos de Abreu. História da Historiografia, Ouro Preto, n. 23, abr. 2017.

FICO, Carlos. Reinventando o otimismo: ditadura, propaganda e imaginário social no Brasil. Rio de Janeiro: FGV, 1997.

. Ditadura militar brasileira: aproximações teóricas e historiográficas. Tempo e Argumento, Florianópolis, v. 9, n. 20, p. 5-74, jan./abr. 2017.

. Violência, trauma e frustração no Brasil e na Argentina: o papel do historiador. Topoi, Rio de Janeiro, v. 14, n. 27, p. 239-261, jul./dez. 2013.

GASPARI, Elio. A ditadura derrotada. São Paulo: Companhia das Letras, 2003. GUMBRECHT, Hans Ulrich. Atmosfera, ambiência, Stimmung: sobre um potencial oculto da literatura. Rio de Janeiro: Contraponto: PUC-Rio, 2014a. 
Será que nada vai acontecer? Tempo e melancolia na poética...

$2014 b$.

. Depois de 1945: latência como origem do presente. São Paulo: Unesp,

LEGIÃO URBANA. V. Rio de Janeiro: EMI-Odeon, 1991. LP.

. As quatro estações. Rio de Janeiro: EMI-Odeon, 1989. LP.

. Que país é este: 1978-1987. Rio de Janeiro: EMI-Odeon, 1987. LP.

. Dois. Rio de Janeiro: EMI-Odeon, 1986. LP.

. Legião Urbana. Rio de Janeiro: EMI-Odeon, 1985. LP.

MAGI, Érica Ribeiro. Rock and roll é o nosso trabalho: a Legião Urbana do underground ao mainstream. São Paulo: Alameda, 2013.

MARCELINO, Douglas Attila. Subversivos e pornográficos: censura de livros e diversões públicas nos anos 1970. Rio de Janeiro: Ministério da Justiça; Arquivo Nacional, 2011.

MARCELO, Carlos. Renato Russo: o filho da revolução. Rio de Janeiro: Agir, 2012.

NAPOLITANO, Marcos. MPB: a trilha sonora da abertura política (1975/1982).

Estudos Avançados, São Paulo, v. 24, n. 69, 2010.

PERALVA, Osvaldo. Feliz ano novo, a sério. Folha de S. Paulo, 2 de janeiro de 1985. Disponível em: 〈http://acervo.folha.uol.com.br/fsp/1985/01/02/21/>. Acesso em: 27 maio 2017.

PIGEAUD, Jackie. Metáfora e melancolia: ensaios médico-filosóficos. Rio de Janeiro: PUC-Rio: Contraponto, 2009.

RUSSO, Renato. Só por hoje e para sempre: diário do recomeço. Organização e notas: Leonardo Lichote. São Paulo: Companhia das Letras, 2015.

SAFATLE, Vladimir. O circuito dos afetos: corpos políticos, desamparo e o fim do indivíduo. Belo Horizonte: Autêntica, 2016.

STAROBINSKI, Jean. A tinta da melancolia: uma história cultural da tristeza. São Paulo: Companhia das Letras, 2016.

VILLA-LOBOS, Dado; DEMIER, Felipe Abranches; MATTOS, Romulo Costa. Dado Villa-Lobos: memórias de um legionário. Rio de Janeiro: Mauad X, 2015.

Recebido em: 15/06/2017

Aprovado em: 20/09/2017

Anos 90, Porto Alegre, v. 24, n. 46, p. 45-70, dez. 2017 